\title{
Consumption and Well-Being
}

DOI:

10.1093/oxfordhb/9780199685271.013.45

\section{Document Version}

Accepted author manuscript

Link to publication record in Manchester Research Explorer

\section{Citation for published version (APA):}

Knights, P., \& O'Neill, J. (2016). Consumption and Well-Being. In T. Gabrielson , C. Hall , J. M. Meyer, \& D. Schlosberg (Eds.), The Oxford Handbook of Environmental Political Theory (pp. 429-439). Oxford University Press. https://doi.org/10.1093/oxfordhb/9780199685271.013.45

\section{Published in:}

The Oxford Handbook of Environmental Political Theory

\section{Citing this paper}

Please note that where the full-text provided on Manchester Research Explorer is the Author Accepted Manuscript or Proof version this may differ from the final Published version. If citing, it is advised that you check and use the publisher's definitive version.

\section{General rights}

Copyright and moral rights for the publications made accessible in the Research Explorer are retained by the authors and/or other copyright owners and it is a condition of accessing publications that users recognise and abide by the legal requirements associated with these rights.

\section{Takedown policy}

If you believe that this document breaches copyright please refer to the University of Manchester's Takedown Procedures [http://man.ac.uk/04Y6Bo] or contact uml.scholarlycommunications@manchester.ac.uk providing relevant details, so we can investigate your claim.

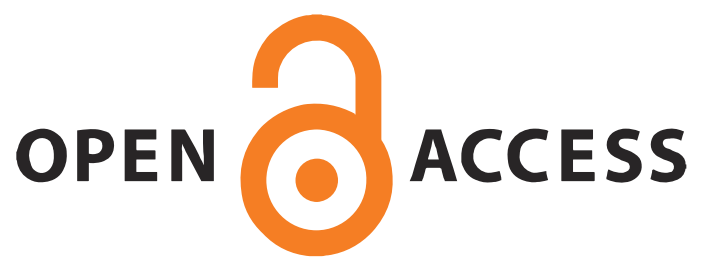


Paul Knights and John O'Neill 'Consumption and Well-Being'. In T. Gabrielson, C. Hall, J. M. Meyer and D, Schlosberg eds. Oxford Handbook of Environmental Political Theory Oxford: Oxford University Press 2016

\section{Abstract and Keywords}

Environmental problems driven by unsustainable consumption are lending new importance to an ancient question: are there bounds to the goods required for a happy or flourishing life? A standard assumption in recent economics is that there are no such bounds. Many further argue that markets, technological change, and resource substitution can deliver sustainability while allowing consumption of final goods by consumers to increase. This chapter criticizes this approach and considers two much older traditions, the Epicurean and Aristotelian, which do recognize the existence of limits to the goods required for the good life. Their revival has been used to argue that consumption can be reduced without loss of well-being. This chapter argues that the promise found by environmentalists in the recent hedonic revival of the Epicurean tradition is misplaced, and that the Aristotelian tradition provides a richer account of why the future-and therefore consuming sustainablymatters to our well-being.

Keywords: consumption, sustainability, limits, well-being, the good life, Epicurean, Aristotelian, markets, technological change

\section{Well-being and Limits}

Recent debates on sustainability, consumption, and happiness have seen the renewal of an ancient controversy: Are there bounds to the goods required for a happy or flourishing life? The classical answer to that question, shared for example in Aristotelian and Epicurean traditions, was that bounds do exist to the goods required for a happy life. That answer survives into some central texts of modern economics, most notably Ramsey's influential paper on saving which still informs basic economic discussion of intergenerational saving. Ramsey assumes that there is a "maximum obtainable rate of enjoyment or utility" which he terms "Bliss" (Ramsey 1928: 545). The point of saving is for a community to achieve that level of goods at which members reach or approximate to Bliss.

While Ramsey's paper remains influential, the specific assumption that there is a maximum state of utility, a point of Bliss, is one that has disappeared from the standard assumptions in economics. The standard economic textbook denies that there are bounds to the goods required for a happy life. Gauthier states the assumption thus: "Appropriation has no natural upper bound. Economic man seeks more" (Gauthier 1986: 318). The question of whether there do or do not exist upper bounds to the goods required for a good life is one that has been brought into new relief by environmental problems and sustainability.

\section{The Concept of Consumption}

The term "consumption" itself is used in a variety of different senses (Williams 1988: 78-9). In its basic sense the concept of consumption is used to refer to the process of using up material and energy in human life processes (Williams 1988: 78-9). To consume is to act such that the availability of an object or resource is reduced (Knights 2012: ch. 1). In that sense, there are strong reasons to assume that if sustainability requires a reduction of 
throughput of energy and materials, then sustainability requires a reduction in consumption. However, the term "consumption" has been extended beyond this in recent uses under the influence of marketing, economics, and other social sciences to include the activities that a person engages in as a "consumer" understood as a purchaser of goods and services in a market. As such reference is made for example to the consumption of images and cultural goods. As Williams notes, the predominance of this market model has meant a further extension of the term into domains such as politics, education, and health. His comment on this extension is still an apposite one: "In any of these fields, but also in the ordinary fields of goods and services, to say user rather than consumer is still to express a relevant distinction" (Williams 1988: 79; emphases in original).

Maintaining this distinction matters for a number of reasons. First, the generalization of a market model of consumption reflects and reproduces a form of marketization. Important social distinctions and relations, for example between citizens in politics, student and teacher in education, patient and doctor in health, and artist and audience in the cultural sphere, each with their associated practices and internal goods, are reduced to the relation of purchaser and provider concerned with the exchange and acquisition of commodities (Keat 1991). A second claim that appeals to the distinction between use and consumption is to be found in the work of Arendt. For Arendt in consumer society the rate of use of objects is accelerated to the point that "the objective difference between use and consumption, between the relative durability of use objects and the swift coming and going of consumer goods dwindles to insignificance" (Arendt 1958: 125). The durable common world of fabricated use objects that are the products of work gives way to a world of consumer goods which are treated as parts of the cycle of labour: "we must consume, devour, as it were, our houses and furniture and cars as though they were the 'good things' of nature which spoil uselessly if they are not drawn swiftly into the neverending cycle of man's metabolism with nature" (Arendt 1958: 126). The reduction of many use objects to objects of consumption undermines our understanding of a common world of fabricated but relevantly stable objects that are shared across generations. Finally, understanding the differences between consumption and other uses of goods is important to conceptualizing the relationships between the good life and the reductions in the use of materials and energy required for sustainability.

In referring to the using up of material and energy, a distinction between two kinds of consumption can be drawn. First, materials and energy are "used up" in the productive process itself-in what is sometimes called "productive consumption" (Marx 1973: 90). Second, there is the consumption of the final objects of the productive processes by consumers. The classical question remains important for sustainability: can a reduction in consumption be achieved without a loss in well-being?

One influential answer to this question is that it can without the need for any reduction in the consumption of final goods by consumers. Shifts in productive activity through technological change and resource substitutability will allow for continuing increases in the consumption of final goods to be pursued with lower energy and resource use. Consumption of raw materials in the productive process itself will be reduced without requiring the reduction in final consumption goods. One recent expression of this view is to be found in the work of Mark Sagoff. While accepting the claim that ever increasing 
consumption of such goods might not be good for us, he rejects the claim that there exist physical and ecological limits to increasing individual consumption or to increased consumption through population growth (Sagoff 2008: 132ff). Since resource and energy limits are a function of technological development, as technology advances so can the frontier of any such limits. As technological development renders final consumption goods less energy and resource intensive, the apparent limits will recede. If state regulation and subsidy did not distort market signals, an innovative market economy could deliver increasing final consumption (Sagoff 2008: 125). The view that markets, technology, and resource substitutability can deliver sustainability with increasing growth in final consumption is widespread in economic literature in both the neo-classical and Austrian traditions.

There are a number of reasons to be sceptical about this view. The first reason has to do with rebound effects that go back to Jevons' paradox (Jevons 1866; Jackson 2009). Falls in the resource and carbon intensity of goods in a market economy will, other things being equal, result in a relative cheapening of the goods. This will either increase consumption or displace it elsewhere, potentially undoing any resource and energy savings. A decline in carbon and material intensity may be a necessary condition for an absolute decline in material and energy use. However, it is not sufficient. The second reason concerns justice in consumption. Development in basic consumption of the least well off is a condition of global justice. However, that increase itself will place large additional burdens on ecological limits. A reduction in luxury consumption is a condition for subsistence consumption to improve as justice requires (Shue 1993). The third reason concerns the time scale for the reduction of greenhouse gases. The avoidance of dangerous climate change requires rapid and deep cuts in the emissions of greenhouse gases that cannot be achieved through technological change alone in the requisite time-span (Anderson and Bows 2011). There are strong reasons for scepticism that technology alone could deliver sustainable outcomes.

If consumption is to decline without a loss of well-being one cannot rely on technological change. The older classical arguments have renewed importance. Are there bounds to the goods required for a good life? The answer depends on the assumptions made about wellbeing and the good life. Recent neo-classical economics assumes a preference satisfaction account of well-being: well-being consists in the satisfaction of preferences, the stronger the preferences, the greater the improvement in well-being. If one assumes that a rational agent will always prefer more to less, it follows that one can always improve wellbeing through offering more. There are no limits to the goods required for a good life. The two main rivals to this account of well-being do recognize the existence of limits: subjective state theories that assume well-being is a matter of being in the right mental states, for example in classical hedonist theories, pleasure and the absence of pain; and objective state theories that assume that well-being consists in the realization of some objective states, such as close personal relations, autonomy, achievement, and knowledge. The Epicurean and Aristotelian answers to the question of limits-that there are bounds to the goods that are required for a good life-are premised for the Epicurean upon a subjective state and the Aristotelian on an objective state account of well-being or happiness. Both have seen revivals as a response to problems of sustainability. 


\section{Two Theories of Well-being}

The revival of hedonic accounts of well-being (Kahneman et al. 1997, 1999; Layard 2005; Frey 2010) has seen a renewed interest in an Epicurean answer to the question of whether there are limits required for the good life. Hedonic accounts of well-being are subjective state accounts of well-being. Well-being is a matter of being in the right mental states. The promise of recent hedonic psychology is that, through both global evaluation and experience sampling methods, states of subjective welfare can be measured and their determinants empirically investigated: "Hedonic psychology . . . is the study of what makes experiences and life pleasant and unpleasant. It is concerned with feelings of pleasure and pain, of interest and boredom, of joy and sorrow and of satisfaction and dissatisfaction" (Kahneman et al. 1999: ix). While this research is often presented as a return to Bentham (Kahneman et al. 1997; Layard 2005), the central environmental claims involve a return to Epicurean themes about the limits of the goods required for a good life. A classical Epicurean theme is that the view that there are no limits to the goods required for a good life is founded on errors about the nature and determinants of happiness. Once the good life is properly understood in hedonic terms, it is evident that there are limits to the goods required for its realization: "Natural wealth is both limited and easy to acquire. But wealth [as defined by] groundless opinions extends without limits" (Epicurus Principal Doctrines 15, in Inwood and Gerson 1988). The claim made by the hedonic environmentalist (for example, Porritt 2003) is that the findings in recent hedonic research confirm this view. Hence a decoupling of consumption and the improvement of well-being is possible. There is evidence that beyond a certain point, growth in GDP is not correlated with a change in reported life satisfaction (Easterlin 1974). While the relative income of different groups within a society is correlated with different levels of life satisfaction, beyond a minimal threshold absolute increases are not. Increasing opportunities for consumption are no longer indicative of increasing wellbeing.

There are two standard explanations of these findings. The first concerns the fact of hedonic adaptation - the tendency of the intensity of at least some good or bad experiences to lessen as individuals adjust to a new state of affairs in which they find themselves. Individuals adapt both to gains in goods - for example to lottery wins - and to losses - for example those who find themselves in wheelchairs after accidents will adjust and after a period their subjective well-being tends to return to previous levels (Frederick and Loewenstein 1999). While changes in circumstances can produce an immediate shift in subjective well-being, over a period individuals adapt and shift to a prior reference point.

The second is an older argument about positional goods that is independent of any hedonic perspective but is still invoked in this context. Positional goods are those goods whose worth depends on their consumption by others. In a market economy where individuals pursue their personal improvement through positional goods each agent makes an individual choice for a good that is affected by the same choice by others and hence there is no increase in life satisfaction (Hirsch 1977). In particular, the race for status and relative income as positional goods is self-defeating. Increased income and consumption is not matched with any increase in life satisfaction.

The consequence of both hedonic adaptation and the pursuit of positional goods is that individuals find themselves on a hedonic treadmill in which as they consume more they 
want more and subjective well-being remains static. The hedonic environmentalist argues that the solution is to pursue those goods that are not subject to these treadmill effects and are shown to be closely correlated to subjective well-being: the quality of familial relationships, the security and intrinsic worth of work, health, personal and political freedoms, and the quality of wider social relationships in a community including in particular the degree of mutual trust within a community. The conclusion that is drawn by the hedonic environmentalist is that we can move to a low consumption economy which sustains happiness.

The promise of hedonism as the basis for the claim that lower consumption can be combined with the maintenance and even possible improvement of well-being has rendered it popular in environmental discourse (Porritt 2003). However, there are major problems with the approach. The first and most basic are the well-known objections to subjective state theories of well-being. Other things matter to well-being in addition to psychological states of feeling good. As Kahneman himself notes in a paper with Sugden: "human wellbeing may be thought to depend, not only on the sum of moment-by-moment affective experiences ... but also on other aspects of life, such as autonomy, freedom, achievement, and the development of deep interpersonal relationships, which cannot be decomposed into momentary affective experiences" (Kahneman and Sugden 2005: 176). The point underpins the standard experience machine objections to hedonism (Nozick 1974: 42-3). We would not agree to enter an experience machine, no matter how reliable it was at giving us all the experiences of a good life of friendship, achievement, and autonomy, since what matters is having friends, realizing certain achievements, etc., not just the experience of having friends, realizing certain achievements, etc. Similarly in the environmental case, we want to actually live in an unspoiled natural environment, not just have the experience of doing so. Given the choice, most of us would desire to live in a natural world, not to live in a simulation of it, even if the experiences were identical.

In addition to these general problems there are more specific difficulties with hedonist accounts of well-being in discussions of intergenerational justice and concern. Consider first intergenerational justice. Hedonic adaptation renders hedonic metrics poor metrics for the purposes of determining injustice generally. The less well-off will adapt to their situation and may not experience it as hard: "A thoroughly deprived person, leading a very reduced life, might not appear to be badly off in terms of the mental metric of desire and its fulfilment, if the hardship is accepted with non-grumbling resignation" (Sen 1992: 55). The point has implications for intergenerational justice since one might expect those in the future who suffer the negative consequences of current decisions to similarly adapt. A world geo-engineered in response to climate change may lack blue skies, a biologically impoverished world may lack many species of flora and fauna we experience today, but the absence of blue skies and biological species may no longer be experienced as a loss but simply a background condition of life. Given adaptation, a subjective wellbeing metric will fail to capture potential harms that matter for intergenerational justice.

Second, hedonic theories of well-being fail to offer an adequate account of why the future matters to us. A central claim in the Epicurean tradition is that what happens after a person's death is a matter of indifference for that person's life: "See likewise of how little concern to us were the ages of eternal time that passed before we were born. Nature holds 
this up to us as a mirror of the time that will be after our death" (Lucretius 1965: Book 3, 972-5). Consequently concern for future generations can only be an impersonal ethical matter that is not tied to how well a person's own life is going. This account fails to acknowledge the ways in which the central projects and relations that constitute our lives have a future beyond our deaths and that the way things turn out matters for how well our lives can be said to go. From intergenerational familial relations, through work activities and political engagements, the way our projects turn out is not a matter of indifference to us (O’Neill 1993: ch. 3).

Can the central claims of recent hedonic research about the possible decoupling of consumption and well-being be retained without being subject to the particular problems associated with hedonism? Objective state theories of well-being promise that they can; the claim that there are limits to the goods required for a good life was articulated by Aristotle: "[T] he amount of household property which suffices for a good life is not unlimited, nor of the nature described by Solon in the verse 'There is no bound to wealth stands fixed for men'. There is a bound fixed ..." (Aristotle 1948: Book 1, ch. 8). According to objective state theories that descend from Aristotle, well-being consists in the realization of certain objective states such as close personal relations, autonomy, achievement, and knowledge. The two central versions of objective state theories of wellbeing appeal to the concepts of needs (Wiggins 1998, 2006; Gough 2014; O'Neill 2010) and of capabilities and functionings (Sen 1995; Nussbaum 2000).

(a) Needs: While some needs claims are purely instrumental to meeting some optional ends - if I am to have a luxury cruise in the Caribbean, then I need $£ 4000$ others are absolute or categorical in the sense that the ends themselves are not optional. Rather the ends are "unforsakeable," a condition of living a minimal level of human flourishing at all, and as such a person can be said to be harmed if they are not met (Wiggins 1998).

(b) Capabilities: The capabilities approach takes individuals' quality of life to be a matter of their freedom to achieve valuable functionings. Functionings are "what people are actually able to do and be" (Nussbaum 2000: 5), and capabilities are the freedoms or opportunities individuals have to achieve those functionings, even if they do not choose to.

The contrast between needs and capabilities approaches to well-being is itself open to some debate. The contrast is undone somewhat if sentences describing needs take a verb phrase as their object, for example, "Joe needs to be able to eat adequately" rather than a noun phrase, for example, "Joe needs food" (Wiggins 2006: 31-2). Thus specified many needs claims will effectively be equivalent to claims about functionings and capabilities. However, some differences may remain. For example, needs claims tend to be about conditions required to achieve functionings rather than capabilities.

Objective state theories of well-being can articulate and defend the claim that there are bounds to the goods required for the good life in two ways. First, in common with hedonic environmentalists, proponents of objective state theories can claim that current consumption levels in richer regions of the world are excessive and are compromising their 
inhabitants' well-being, such that a reduction in consumption is compatible with maintaining or even improving well-being (Jackson and Marks 1999; Stiglitz et al. 2009: ch.2). Secondly, unlike hedonic environmentalism, objective state theorists can claim that current consumption levels compromise the well-being of present generations insofar as they decrease the likelihood that future generations will be in a position to continue, appreciate, preserve, and value the projects that were of importance to us. With regard to the first argument, appeal can be made to empirical data which shows that rising GDP, above a certain level, is not correlated with improvements in capabilities to achieve valuable functionings (Stiglitz et al. 2009: ch. 2). However, appeal may also be made to data which is commonly assumed as emerging from firmly within the hedonic tradition. Much is made within the recent revival of Epicurean hedonism of the empirical data on reported life satisfaction which appears to show that while per capita consumption has risen in the past 60 years within rich countries, aggregate welfare has plateaued over this period. This data is derived from the World Values Survey and the Gallup World Poll, both of which ask the question: "All things considered, how satisfied are you with your life as a whole these days?" Respondents rank their answer on a scale from 1 (dissatisfied) to 10 (satisfied). In order for the data derived from the answers given by respondents to this question to be understood as pertaining to subjective wellbeing it must be the case that respondents understand the concept of "satisfaction" to be referring only to psychological states, and to be asking them to sum particular episodes of happy feelings. But it is highly plausible that the life satisfaction survey question is understood by respondents to be calling for them to assess not only their subjective states of feeling good and feeling bad, but also what they have been able to do and become in dimensions of their life that are significant to them. This requires an assessment of the more objective conditions of their life, such as the quality of their neighbourhood for bringing up their children, housing, opportunities for leisure, the quality of their work life, and so on. The assumption that the data only reveals subjective well-being appears to be at least partly due to a scope fallacy, where "a subjective assessment of well-being" and "an assessment of subjective well-being" are conflated (O'Neill 2006). Life satisfaction surveys can be understood to be surveys of subjective assessments of objective well-being. How far this data itself adequately tracks objective assessments of objective well-being remains an important problem. Since a person's assessment of the achievement of a particular level of objective well-being will itself depend on the person's expectations, subjective assessments of objective well-being can themselves be subject to the problems of adaptation. A person with low functioning might assess an improved condition highly, whereas a person with a high state of functioning might give a low assessment to that condition if it is the outcome of a loss.

The second argument that objective state theorists can make to the effect that current consumption levels compromise the well-being of present generations is that they do so in virtue of the effect that unsustainable consumption is likely to have on the capacity of future generations to be in a position to continue, appreciate, preserve, and value the projects that were of importance to us. Unlike hedonism, objective state theories of wellbeing can provide an account of how the way the future turns out has a bearing on how well our life can be said to be going now. It can do this by claiming that the welfare value of particular moments, or episodes within larger time frames, cannot be ascertained independently of the larger narrative structure in which they occur. The future determines what appraisal we can give to the present (O'Neill 1993: ch. 3, 2006). This applies not only 
within lives, but also, crucially, to what happens after our deaths, since the narrative that can truly be told of our lives will often include reference to the way that central projects and relationships that were important to us when we were alive fared after our death. Hedonism fails to provide such an account. If all that matters to the welfare value of some event at any moment of time is the quality of the experience at that moment then this can be ascertained quite independently of what happens at any moment before or after. It is fixed by the quality of the experience at that instant. Whether or not the event was pleasurable or painful and by how much can be ascertained independently of what happened before or after (O'Neill 2006: 163). In failing to allow that what happens after our deaths matters to an appraisal of how well our lives are going now, hedonism cannot explain why consuming sustainably, such that future generations are bequeathed the conditions that make it possible for them to continue our current important projects, matters for how well our lives go. Articulations of arguments for sustainable consumption that are grounded in objective state theories of well-being, however, can allow that the future matters to us.

The shortening of time horizons that is a feature of a market economy and consumer society undermines such cross generational projects. This point was central to classical republican political thought and underpins Arendt's distinction between use and consumption noted earlier. For Arendt, in consumer societies public objects like buildings are built not as ties over generations but as goods that are created and destroyed like objects that are literally consumed. The temporal cycles of markets and the competition for political office undermine commitments to projects with a longer time frame to come to fruition. Such projects give individuals a stake in the future. Neither, in these conditions, can we expect that future generations will preserve and value the scientific, political, and cultural projects of central importance to current generations. In this way, objective state theorists can argue that the narrative of current generations will be ended tragically, and this appraisal affects how well our lives can be said to be going now, providing a kind of reason to consume sustainably relating to our own well-being that hedonism cannot. Thus, in the context of a new environmental situation in which future generations are threatened with degraded conditions of life, a new justification to the claim that there are bounds to the goods required for a good life emerges; we cannot be said to be living a good life if the central projects of importance to us that we believed or hoped would be continued and valued by future generations will be abandoned by them as a result of our unwillingness to create and support institutions that secured the conditions for them to be able do so.

\section{The Sources of Consumption without Limits}

Aristotelian and Epicurean approaches to well-being, while sharing the view that there are bounds to the goods required for the good life, offer different accounts of the nature of well-being. There is, however, a second way in which they differ in their account of the limits, namely their account of the explanation as to why individuals pursue goods without bounds. The explanations are independent of the specific theories of well-being. Epicurus's account of the source of the limitless pursuit of goods is a purely cognitive one. Individuals pursue goods without limits due to false beliefs. "The stomach is not insatiable as the many say, but rather the opinion that the stomach requires an unlimited amount of filling is false" (Epicurus Vatican Sayings 59, in Inwood and Gerson 1988: 31). This view is echoed in more recent work on happiness within the psychological literature which similarly 
tends to take the source of the pursuit of goods without limits to lie in cognitive errors by individuals. In contrast, Aristotle's answer is institutional. He contrasts the form of acquisition of goods in the classical household, in which acquisition is limited by the needs of householders, with the forms of acquisition that are characteristic of commercial society in which wealth is pursued for its own sake and acquisition appears to lack limits: "There is no limit to the end it seeks; and the end it seeks is wealth of the sort we have mentioned [that is, wealth in the form of currency] and the mere acquisition of money" (Aristotle 1948: Book 1, ch. 8). This distinction between two modes of acquisition has been influential in more recent critical discussion of market societies (O'Neill 1993: ch. 10). Marx explicitly appeals to it in Capital. Where he differs from Aristotle is in his claim that acquisition without limits is not simply a vice, pleonoxia, that is fostered by market society, but rather, in the form of capital accumulation, is an activity that is required by the capitalist to survive against competitors (Marx 1970: ch. 4). Polanyi also takes Aristotle's distinction as his starting point for understanding the ways in which market societies disembed the economy from social and moral relations (Polanyi 1957: 53-5). The structural and institutional determinants of consumption without limits matter. We live in economies in which increasing consumption is a condition for the stability and reproduction of the economic system itself-where falls in "consumer confidence" are indications of an economy in crisis. This argument is important in considering responses to the gap between increasing consumption and static or even declining well-being. To frame the solution in Epicurean terms of shifting the beliefs and values of consumers fails to address the structural determinants of increasing consumption. Political and economic responses to consumption and sustainability need to address not just false beliefs but the institutional and structural determinants of behaviour and hence address again fundamental questions in political economy about the organization of economic life.

\section{References}

Anderson, K. and Bows, A. (2011). "Beyond 'Dangerous' Climate Change: Emission Scenarios for a New World." Philosophical Transactions of the Royal Society A 369: 20-44. Arendt, H. (1958). The Human Condition (Chicago: University of Chicago Press). Aristotle. (1948). Politics. Translated by E. Barker (Oxford: Clarendon Press). Easterlin, R. (1974). "Does Economic Growth Improve the Human Lot? Some Empirical Evidence." In Nations and Households in Economic Growth: Essays in Honor of Moses Abramovitz, edited by P. A. David and M. W. Reder (London: Academic Press), 89-125. Frederick, S. and Loewenstein, G. (1999). "Hedonic Adaptation." In Scientific Perspectives on Enjoyment, Suffering, and Well-Being, edited by D. Kahneman, E. Diener, and N. Schwartz (New York: Russell Sage Foundation), 302-29.

Frey, B. (2010). Happiness: A Revolution in Economics (Cambridge, MA: MIT Press). Gauthier, D. (1986). Morals by Agreement (Oxford: Oxford University Press).

Gough, I. (2014). Climate Change and Sustainable Welfare: The Centrality of Human Needs (London: NEF working paper).

Hirsch, Fred. (1977). Social Limits to Growth (London: Routledge, Kegan and Paul). Inwood, B. and Gerson, L., eds. (1988) Hellenistic Philosophy (Indianapolis: Hackett). Jackson, T. (2009) Prosperity without Growth (London: Earthscan). Jackson, T. and Marks, N. (1999). "Consumption, Sustainable Welfare and Human Needs With Reference to UK Expenditure Patterns Between 1954 and 1994." Ecological Economics 28: 421-41. 
Jevons, W. (1866). The Coal Question, 2nd edn. (London: Macmillan and Co).

Kahneman, D. and Sugden, R. (2005). "Experienced Utility as a Standard of Policy

Evaluation." Environmental \& Resource Economics 32: 161-81.

Kahneman, D., Wakker, P., and Sarin, R. (1997). "Back to Bentham? Explorations of

Experienced Utility." The Quarterly Journal of Economics 112: 375-405.

Kahneman, D., Diener E., and Schwarz N., eds. (1999). Well-Being: Foundations of Hedonic

Psychology (New York: Russell Sage Foundation Press).

Keat, R. (1991). "Consumer Sovereignty and the Integrity of Practices." In Enterprise Culture, edited by R. Keat and N. Abercrombie (London: Routledge), 216-30.

Knights, P. (2012). Consumption, Environment and Ethics: An Analysis of Moral and Welfare Arguments for Reducing Personal Consumption (Ph.D. Thesis, University of Manchester).

Layard, R. (2005). Happiness: Lessons for a New Science (London: Allen Lane).

Lucretius. (1965). On Nature. Translated by R. Greer (Indianapolis: Bobbs-Merrill).

Marx, K. (1970). Capital I (London: Lawrence and Wishart).

Marx, K. (1973). Grundrisse (Harmondsworth: Penguin).

Nozick, R. (1974). Anarchy, State and Utopia (Oxford: Blackwell).

Nussbaum, M. (2000). Women and Human Development: The Capabilities Approach

(Cambridge: Cambridge University Press).

O'Neill, J. (1993). Ecology, Policy and Politics: Human Well-Being and the Natural World

(London: Routledge).

O’Neill, J. (2006). “Citizenship, Well-Being and Sustainability: Epicurus or Aristotle?"

Analyse \& Kritik 28: 158-72.

O’Neill, J. (2010). "The Overshadowing of Need." In Sustainable Development: Capabilities, Needs, and Well-Being, edited by F. Rauschmayer, I. Omann, and J. Frühmann (London:

Routledge), 25-42.

Polanyi, K. (1957). The Great Transformation (Boston: Beacon Press).

Porritt, J. (2003). Redefining Prosperity: Resource Productivity, Economic Growth and

Sustainable Development (London: Sustainable Development Commission).

Ramsey, F. P. (1928). "A Mathematical Theory of Saving." Economic Journal 38: 543-59.

Sagoff. M. (2008). The Economy of the Earth, 2nd edn. (Cambridge: Cambridge University

Press).

Sen A. (1992). Inequality Reexamined (Oxford: Clarendon Press).

Sen, A. (1995). Development as Freedom (Oxford: Oxford University Press).

Shue, Henry. (1993). "Subsistence Emissions and Luxury Emissions." Law and Policy 15: 3960.

Stiglitz, J. et al. (2009) Report by the Commission on the Measurement of Economic

Performance and Social Progress

Wiggins, D. (1998). "The Claims of Need." In D. Wiggins, Needs, Values, Truth, 3rd edn.

(Oxford: Clarendon Press), 1-58.

Wiggins, D. (2006). "An Idea We Cannot Do Without." In The Philosophy of Need, edited by

S. Reader (Cambridge: Cambridge University Press), 25-50.

Williams, R. (1988). Keywords (London: Fontana). 